Dikumpulkan : 28 Februari 2017

Direvisi : 22 Maret 2017

Diterima : 25 Maret 2017

\title{
Layanan Makanan dan Minuman di Hotel Amaris Diponegoro Yogyakarta
}

\author{
ERLIN ESTIANA YUANTI, LIDIA CITRA LUCKYRAINITA \\ Diploma Bahasa Inggris, Sekolah Vokasi, Universitas Gadjah Mada \\ erlin_estiana@ugm.ac.id; luckyrainita@gmail.com
}

\begin{abstract}
The purpose of the research is to explain about the profile of food and beverage department in Amaris Hotel Diponegoro Jogja. In addition, the services provided by $\mathrm{F} \& \mathrm{~B}$ department will also be discussed along with the challenges faced by the staff in $F \& B$ department. The methods used in this research consist of field study and library study. The field study was done in the form of direct observation and some interviews. Besides, the library study was also conducted to gaininformation from books, ebook, internet sources, and the handout obtained from Amaris Hotel Diponegoro Jogja including information on its human resources and the food and beverage department databases.Based on the finding obtained from the research, Amaris Hotel Diponegoro Jogja offers the basic standard facilities to the guests, namely bed and breakfast. The breakfast service was handled by the food and beverage department. In addition to the breakfast service, the food and beverage department also serves welcome drink service, meeting and banquet service, table service, and room service. The research also obtains several challenges faced by the staff in the food and beverage department, such as the time management, the communication among the kitchen staffs and the guests. To solve the challenges respectively, some ways were applied by the F \& B staff, such as sharing jobs, holding intensive briefings, and also paying attention to the guests' requests and giving service to the guests according to their requests.
\end{abstract}

Keywords:

Food and Beverage, Service, Amaris Hotel Diponegoro, Yogyakarta 


\section{Pendahuluan}

Yogyakarta merupakan salah satu daerah tujuan wisata di Indonesia. Berbagai tempat tujuan wisata di Yogyakarta menjadi magnet bagi wisatawan baik domestik maupun mancanegara. Seiring dengan perkembangan industri wisata di Yogyakarta, sarana akomodasi memiliki peran penting bagi wisatawan yang menginginkan untuk tinggal selama beberapa hari.

Jenis hotel di Yogyakarta terdiri dari hotel berbintang maupun non bintang. Pengklasifikasian hotel ini didasarkan pada standar tertentu sesuai fasilitas yang dimiliki masing-masing hotel (Elements of Business Skills, 2015). Badan Pusat Statistik Yogyakarta mencatat ada sebanyak 57 hotel berbintang dan 362 hotel non bintang di Kota Yogyakarta pada kurun waktu 2006-2015. Selain untuk memenuhi kebutuhan akomodasi wisatawan, beberapa hotel juga menawarkan layanan MICE atau Meeting, Incentives, Conferences, dan Events. Hotel wajib memiliki beberapa fasilitas standar dalam memberikan pelayanan baik bagi wisatawan maupun untuk keperluan MICE, seperti fasilitas dan layanan makanan dan minuman atau Food and Beverage, layanan petugas ruangan atau room service, dan sebagainya "("Perbedaan Antara Hotel dan Motel", 2015). Standar tersebut menunjukkan bahwa layanan $\mathrm{F} \& \mathrm{~B}$ merupakan salah satu layanan yang mutlak ada di setiap hotel. Departemen F \& B merupakan bagian penting yang berperan dalam menyiapkan dan menyajikan makanan dan minuman kepada tamu hotel. Davis dan Stone (1985) menyatakan bahwa departemen F \& B ikut menyumbang pemasukan hotel sebesar 20 $\%$ hingga $40 \%$.

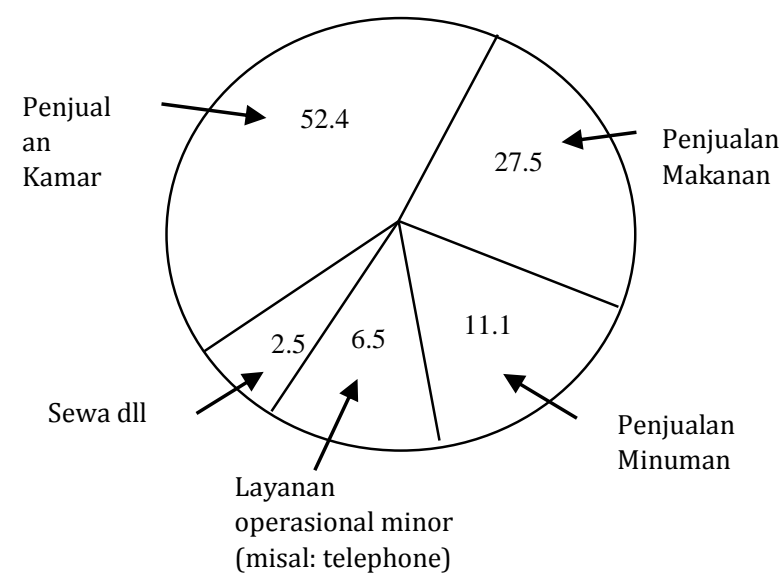

Gambar 1. Prosentase Penerimaan Hotel Internasional, 1983

Sumber: Horwath \& Horwath International and Laventhol and Horwath Worldwide Lodging Industry, 1984

Berdasarkan diagram di atas dapat dilihat bahwa hotel internasional mendapatkan penerimaan terbesar dari penjualan kamar yaitu sebanyak 52, $4 \%$. Sumber penerimaan besar selanjutnya adalah penjualan makanan $(27,5 \%)$ dan penjualan minuman (11, 1\%). Fakta tersebut menegaskan pentingnya peran Departemen F \& B di sebuah hotel. Oleh karena itu, penelitian ini akan membahas layanan F \& B di salah satu hotel di Yogyakarta yaituHotel Amaris Diponegoro Yogyakarta.

Hotel Amaris Diponegoro Yogyakarta merupakan salah satu hotel berbintang dua di Yogyakarta yang dimiliki dan dikelola oleh PT. Grahawita Santika yang juga mengelola Santika Indonesia Hotels and Resorts. Lokasinya yang strategis di Jalan Diponegoro 87 Yogyakarta membuat hotel ini mudah diakses. Hotel ini merupakan budget hotel yang menyediakan fasilitas berupa kamar tidur dan sarapan atau yang lebih sering dikenal dengan bed and breakfast. Selain menyediakan kamar dan layanan sarapan, hotel ini juga menyediakan layanan 
makanan dan minuman yang lain, seperti welcome drink, layanan rapat dan banquet, layanan meja dan layanan kamar. Semua layanan tersebut dilakukan oleh staf Departemen F \& B Hotel Amaris. Dari wawancara dengan Saputra (2015), salah satu koki di Hotel Amaris,diketahui bahwa departemen $F$ \& B di Hotel Amaris Diponegoro Yogyakarta menyumbang pemasukan hotel sebesar $20 \%$. Penelitian ini membahas profil Departemen $F$ \& B Hotel Amaris Diponegoro Yogyakarta, layanan makanan dan minuman di Hotel Amaris Diponegoro Yogyakarta beserta tantangan yang dihadapi staf F \& B di Hotel Amaris Diponegoro Yogyakarta.

\section{Metode}

Pengumpulan data dilakukan dengan melaksanakan studi lapangan dan studi kepustakaan. Studi lapangan dilakukan di Hotel Amaris Diponegoro Yogyakarta selama 2 bulan dari 16 Maret 2015 hingga 15 Mei 2015 melalui program magang di Departemen F \& B Hotel Amaris Diponegoro Yogyakarta. Selama periode magang, penulis melakukan observasi dan wawancara. Observasi dilakukan terkait operasional Departemen F \& B Hotel Amaris Diponegoro Yogyakarta yang didukung dengan dokumentasi berupa foto. Sedangkan wawancara dilakukan dengan koki serta pelayan, staf SDM, pengawas operasional dan salah satu staf resepsionis Hotel Amaris Diponegoro Yogyakarta. Wawancara dilakukan dengan teknik pencatatan dan rekaman. Studi Kepustakaan dilakukan dengan membaca informasi tambahan dari buku, e-book, sumber internet dan hand out tentang hotel dan Departemen $\mathrm{F}$ \& B secara umum dan tentang Hotel Amaris Diponegoro Yogyakarta.

\begin{abstract}
Data yang dihasilkan dianalisa dengan pendekatan kualitatif dan diinterpretasikan sesuai dengan tujuan studi. Data disajikan dalam bentuk deskriptif yang berupa paragraf yang didukung dengan tabel dan gambar untuk memberikan pembahasan yang lebih jelas.
\end{abstract}

\section{Hasil dan Pembahasan}

Penjelasan berikut akan disampaikan hasil dan pembahasan terkait Profil F \& B Hotel Amaris Diponegoro Yogyakarta, layanan F \& B, dan tantangan yang dihadapi oleh staf Departemen $\mathrm{F} \& \mathrm{~B}$.

\section{Profil Departemen F \& B Hotel Amaris Diponegoro Yogyakarta}

Menurut Pendit dan Soekresno (1998: 4) F \& B department adalah bagian darihotel yang mengurusi makanan dan minuman serta kebutuhan lain yang terkait dengan para tamu yang menginap maupun yang tidak menginap di hotel tersebut dan dikelola secara komersial serta professional. Sedangkan menurut Sulastiyono (1999:189), fungsi departemen F \& B antara lain:

1. melaksanakan usaha pengembangan produk makanan dan minuman

2. merencanakan kegiatan yang dapat menarik tamu untuk makan dan minum

3. melakukan penyimpanan bahanbahan makanan dan minuman

4. melakukan pengelolaan makanan dan minuman

5. melakukan penyimpanan makanan dan minuman

6. melakukan penghitungan produk

Departemen F \& B Hotel Amaris tidak memiliki struktur organisasi resmi karena semua staf dapur dianggap memiliki posisi dan tanggung jawab yang 
sama. Menurut informasi dari F \& B Hotel Amaris Diponegoro Yogyakarta, staf dapur memiliki beberapa tugas, sebagai berikut:

1. Menata meja di @Xpress untuk layanan sarapan dan Amara Ballroom untuk layanan rapat dan banquet sesuai standar;

2. Menyapa tamu sebelum makan pagi, makan siang dan makan malam dan mengucapkan terima kasih kepada tamu setelah selesai menyantap makanan;

3. Memastikan tiap tamu mendapatkan layanan professional yang menyenangkan;

4. Membersihkan meja dan membawa peralatan makan yang kotor;

5. Membuang sisa makanan ke tempat sampah tiap waktu makan;

6. Merapikan peralatan makan ke rak;

7. Mengelap peralatan makan dan minum menggunakan lap bersih;

8. Merawat peralatan makan dan minum agar tidak pecah;

9. Menyiapkan dan memasak makan pagi, makan siang, dan makan malam sesuai resep standar;

10. Mengecek stok sarapan secara teratur untuk memastikan tamu mendapatkan sarapan dan menambah stok sarapan;

11. Menjaga kebersihan area dapur dan @xpress;

12. Menjaga kualitas makanan dan minuman di lemari pendingin dan penyimpanan;

13. Memasak sesuai standar resep dan mengikuti prosedur.

Dari ke-13 tugas di atas, dapat dilihat bahwa staf F \& B Hotel Amaris Yogyakarta belum menjalankan fungsi pengembangan produk makanan dan minuman dan merencanakan kegiatan yang menarik untuk menarik tamu untuk makan dan minum. Selain itu, tidak adanya struktur organisasi yang jelas merupakan tantangan tersendiri bagi para staf dalam menjalankan tugas.

Terdapat 4 koki dan 1 pelayan di Hotel Amaris. Walaupun belum ada struktur organisasi resmi, di bagian $F \& B$, Koki Rio ditunjuk sebagai pemimpin untuk menangani segala macam keperluan dapur. Koki Rio merupakan koki senior yang telah bekerja selama 3 tahun sejak Maret 2011. Koki Rio merupakan lulusan Diploma III Pariwisata dan telah melakukan magang selama 6 bulan di Santika Hotel Premiere Yogyakarta. Selanjutnya Koki Heri adalah koki yang mulai bekerja sejak Maret 2014. Sebelumnya, Koki Heri bekerja di sebuah restaurant. Koki Ani adalah koki perempuan satu-satunya di Hotel Amaris Diponegoro Yogyakarta. Koki Ani lulus dari Diploma I perhotelan dan pernah magang di Hotel Saphir dan Hotel Sahid. Koki yang terakhir adalah Koki Wikan yang baru bergabung pada April 2015. Koki Wikan pernah mendapatkan training pekerjeaan selama 3 bulan di Hotel Amaris. Satu pelayan di Departemen F \& B adalah Mulyanto. Mulyanto bekerja 5 hari seminggu dan bertugas mencuci peralatan masak dan makan serta membantu koki. Selain itu, ada juga beberapa trainee yang membantu koki dan pelayan mencuci dan mengelap peralatan makan, menyapa tamu saat layanan sarapan, mengantarkan menu saat rapat dan banquet dari dapur ke @Xpress atau Amara Ballroom.

Setiap staf dapur bekerja dalam tiga pilihan waktu, yaitu shift pagi, tengah dan malam. Koki yang bertugas pada shift pagi bertanggung jawab penuh atas layanan sarapan dan layanan rapat dan banquet jika ada. Jika ada acara di malam hari, maka koki yang bertugas pada shift tengah 
bertanggung jawab menyiapkan semua keperluan. Koki yang bertugas pada shift malam memiliki tugas yang sama yaitu memasak makan malam dan menyiapkan menu sarapan untuk keesokan paginya.

\section{Layanan F \& B di Hotel Amaris Diponegoro Yogyakarta}

Terdapat beberapa topik terkait $F \&$ $B$, seperti manajemen $F \& B$, layanan $F \& B$, produk $F \& B$, promosi penjualan $F \& B$, pengendalian biaya $F \& B$, dan sebagainya. Pada bagian ini akan diuraikan layanan $\mathrm{F} \&$ B di Hotel Amaris Diponegoro Yogyakarta. Kazarian (1983) menyatakan ada dua metode dasar layanan terkait makanan, yaitu service unit dan self-service unit. Service Unit meliputi layanan meja, layanan counter, layanan booth dan layanan kamar, sedangkan Self-service unit meliputi layanan di kafetaria, layanan buffet, layanan take out, dan layanan vending. Berdasarkan pernyataan tersebut, Hotel Amaris mengadopsi kedua metode namun hanya memiliki beberapa layanan saja. Service unit di Hotel Amaris terdiri dari layanan meja dan layanan kamar. Kemudian layanan buffet sebagai selfservice unit ditransformasikan menjadi layanan sarapan, layanan welcomedrink, layanan rapat dan banquet. Untuk lebih jelasnya, masing-masing layanan akan dijelaskan sebagai berikut:

\section{a. Layanan Sarapan}

Layanan sarapan dimulai dari jam 6 hingga jam 10 pagi. Konsep sarapan di Hotel Amaris Diponegoro Yogyakarta adalah buffet sederhana seperti terlihat pada gambar 2. Para tamu hotel dapat mengambil sendiri menu makan pagi dan minuman yang telah disediakan. Menu utama untuk sarapan adalah masakan tradisional yaitu brongkos. Selain itu ada menu pelengkap lain seperti bubur ayam, roti bakar, berbagai jenis olahan telur, sosis, buah dan pudding. Layanan sarapan juga terdapat berbagai jenis minuman seperti teh, kopi, jus, dan air mineral.

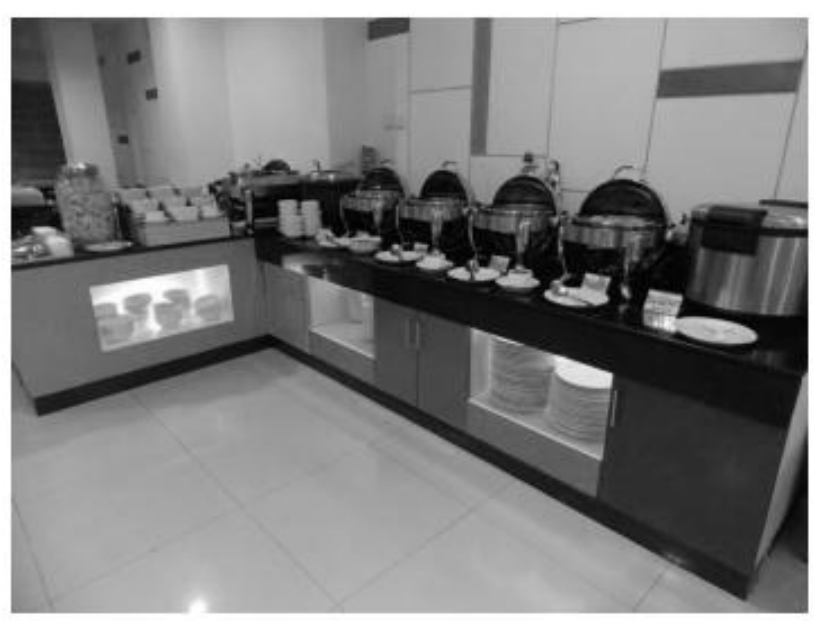

Gambar 2. Layanan sarapan dengan konsep Buffet sederhana

Sumber: Luckyrainita, 14 Mei 2015

Pada saat sarapan, tamu hotel harus menyerahkan kupon sarapan mereka kepada staf sehingga mereka dapat makan dan minum di @Xpress. Kupon sarapan hanya tersedia untuk 2 orang sekali makan. Jika ada tamu hotel yang hendak makan lagi atau tamu yang tidak menginap tetapi ingin sarapan di hotel, mereka harus membayar Rp 35.000 per orang untuk paket all you can eat.

Menurut Koki Saputra, PT. Grahawita Santika telah membuat standar untuk semua resep, menu, dan rotasi menu sarapan untuk semua Hotel Amaris di Indonesia. Pembuatan standar dimaksudkan untuk menjaga kualitas makanan dan minuman yang disediakan.

Terkait rotasi menu sarapan, para koki harus sepakat untuk mengikuti rotasi menu yang disediakan mulai dari awal bulan. Terdapat 16 menu sarapan di Hotel Amaris untuk tanggal 1-16 setiap bulannya. 
Sedangkan untuk tanggal 17 dan seterusnya, menu sarapan diulang dari awal. Komunikasi yang bagus mutlak diperlukan dalam penyiapan menu sarapan sehingga tidak ada pengulangan sajian setiap hari. Berikut sampel rotasi menu sarapan untuk 4 hari berturut-turut:

Tabel 1. Rotasi Menu Sarapan

\begin{tabular}{|c|c|c|c|}
\hline I & II & III & IV \\
\hline Nasi & Nasi & Nasi & Nasi \\
\hline $\begin{array}{l}\text { Nasi } \\
\text { Goreng } \\
\text { Tradisiona } \\
\text { I }\end{array}$ & $\begin{array}{l}\text { Nasi } \\
\text { Goreng } \\
\text { Telur }\end{array}$ & $\begin{array}{l}\text { Nasi } \\
\text { Goreng } \\
\text { Jambal }\end{array}$ & $\begin{array}{l}\text { Nasi } \\
\text { Goreng } \\
\text { Mawut }\end{array}$ \\
\hline $\begin{array}{l}\text { Tumis } \\
\text { Kacang } \\
\text { Panjang }\end{array}$ & $\begin{array}{l}\text { Cah } \\
\text { Selada }\end{array}$ & $\begin{array}{l}\text { Tumis } \\
\text { Buncis }\end{array}$ & $\begin{array}{l}\text { Sayur } \\
\text { santan }\end{array}$ \\
\hline $\begin{array}{l}\text { Mie } \\
\text { Goreng }\end{array}$ & $\begin{array}{l}\text { Bihun } \\
\text { Goreng }\end{array}$ & $\begin{array}{l}\text { Soun } \\
\text { Goreng }\end{array}$ & $\begin{array}{l}\text { Kwetiau } \\
\text { Goreng }\end{array}$ \\
\hline $\begin{array}{l}\text { Ayam } \\
\text { Goreng } \\
\text { Bacem }\end{array}$ & $\begin{array}{l}\text { Ikan } \\
\text { Goreng } \\
\text { Lombok } \\
\text { ljo }\end{array}$ & $\begin{array}{l}\text { Gulai } \\
\text { ayam }\end{array}$ & $\begin{array}{l}\text { Ayam } \\
\text { Goreng } \\
\text { Krispy }\end{array}$ \\
\hline $\begin{array}{l}\text { Olahan } \\
\text { telur }\end{array}$ & $\begin{array}{l}\text { Olahan } \\
\text { telur }\end{array}$ & $\begin{array}{l}\text { Olahan } \\
\text { Telur }\end{array}$ & $\begin{array}{l}\text { Olahan } \\
\text { Telur }\end{array}$ \\
\hline Brongkos & Brongkos & Brongkos & Brongkos \\
\hline Roti bakar & $\begin{array}{l}\text { Roti } \\
\text { bakar }\end{array}$ & $\begin{array}{l}\text { Roti } \\
\text { bakar }\end{array}$ & $\begin{array}{l}\text { Roti } \\
\text { bakar }\end{array}$ \\
\hline selai & selai & selai & selai \\
\hline $\begin{array}{ll}2 & \text { jenis } \\
\text { sirup/ jus }\end{array}$ & $\begin{array}{l}2 \quad \text { jenis } \\
\text { sirup/jus }\end{array}$ & $\begin{array}{l}2 \quad \text { jenis } \\
\text { sirup/ jus }\end{array}$ & $\begin{array}{l}2 \quad \text { jenis } \\
\text { sirup/ jus }\end{array}$ \\
\hline $\begin{array}{l}\text { Kopi dan } \\
\text { teh }\end{array}$ & $\begin{array}{l}\text { Kopi dan } \\
\text { teh }\end{array}$ & $\begin{array}{l}\text { Kopi dan } \\
\text { teh }\end{array}$ & $\begin{array}{l}\text { Kopi dan } \\
\text { teh }\end{array}$ \\
\hline pepaya & $\begin{array}{l}\text { semangk } \\
\text { a }\end{array}$ & $\begin{array}{l}\text { semangk } \\
\text { a }\end{array}$ & $\begin{array}{l}\text { semangk } \\
\text { a }\end{array}$ \\
\hline melon & pepaya & pepaya & pepaya \\
\hline $\begin{array}{l}\text { Gorengan } \\
\text { / rebusan }\end{array}$ & $\begin{array}{l}\text { Gorengan } \\
\text { / rebusan }\end{array}$ & $\begin{array}{l}\text { Gorengan } \\
\text { / rebusan }\end{array}$ & $\begin{array}{l}\text { Gorengan } \\
\text { / rebusan }\end{array}$ \\
\hline $\begin{array}{l}\text { Bubur } \\
\text { ayam dan } \\
\text { kuah sup } \\
\text { kaldu }\end{array}$ & $\begin{array}{l}\text { Bubur } \\
\text { ayam dan } \\
\text { kuah sup } \\
\text { kaldu }\end{array}$ & $\begin{array}{l}\text { Bubur } \\
\text { ayam dan } \\
\text { kuah sup } \\
\text { kaldu }\end{array}$ & $\begin{array}{l}\text { Bubur } \\
\text { ayam dan } \\
\text { kuah sup } \\
\text { kaldu }\end{array}$ \\
\hline
\end{tabular}

Sumber: Data dari Departemen F \& B Hotel Amaris

Staf dapur yang bertugas selama jam layanan sarapan terdiri dari 2 orang koki, 1 pramusaji dan 1 trainee. Koki bertanggung jawab atas apapun selama jam makan pagi, sedangkan pramusaji dan trainee bertugas mencuci semua alat makan dan membantu koki.

\section{b. Layanan Welcome Drink}

Tamu yang datang ke Hotel Amaris mulai jam 14.00 hingga 22.00 diberikanwelcome drink. Layanan ini merupakan fasilitas yang didapatkan tamu Hotel Amaris selain sarapan. Tamu dapat mengambil sendiri dan membawa minuman selamat datang ini ke kamar

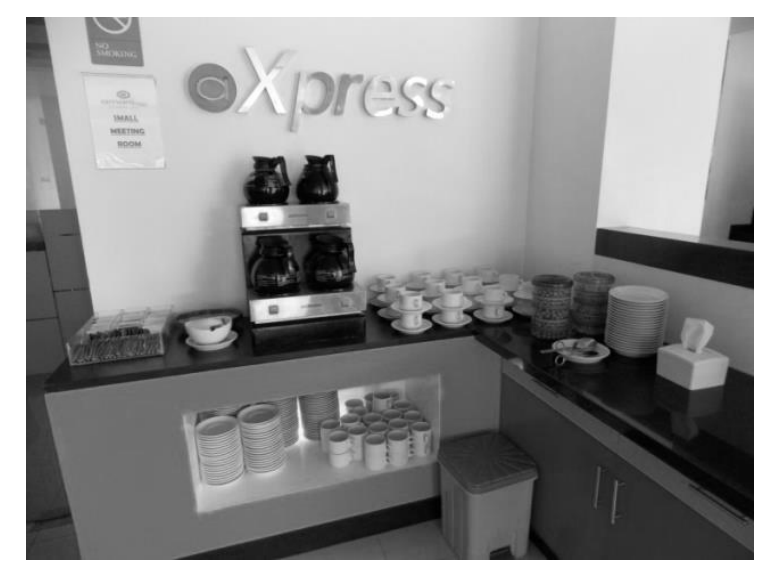

mereka.

\section{Gambar 3. Layanan Welcome Drink \\ Sumber: Luckyrainita, 14 Mei 2015}

Menu welcome drink di Hotel Amaris antara lain kopi dan teh tawar. Tamu dapat menambahkan sendiri gula sesuai selera. Selain teh dan kopi, welcome drink di Hotel Amaris juga dilengkapi dengan makanan ringan seperti aneka macam kacang dan keripik.

Layanan Welcome Drink ini juga disiapkan untuk tamu yang tidak menginap dengan harga Rp 25.00o per orang. Mereka dapat menikmati makanan dan minuman Welcome Drinkini di @xpress.

Koki dibantu oleh staf Resepsionis dan staf keamanan dalam menyiapkan layanan Welcome Drink ini. Koki yang bertugas pada setiap shift harus 
melakukan pengecekan terhadap ketersediaan makanan dan minuman dalam layanan welcome drink ini secara berkala, paling lama tiap dua jam. Terkait pengecekan, koki perlu mengganti kopi dan teh dan menambah makanan ringan. Jika staf dapur sedang sibuk, staf resepsionis akan membantu mereka mengganti kopi dan teh serta menambah sediaan makanan ringan.

\section{c. Layanan Rapat dan Banquet}

Layanan rapat dan banquet merupakan layanan F\& B yang wajib ada di sebuah hotel. Trainor, executive chef Hilton menyampaikan bahwa pihak hotel dituntut untuk kreatif dalam menandingi menu banquet a la carte yang ditawarkan restoran pada umumnya. Hotel Amaris Diponegoro Yogyakarta menyediakan layanan rapat dan banquet atau jamuan makan malam formal kepada tamu yang hendak mengadakan rapat, pertemuan atau acara lainnya.

Hotel Amaris Diponegoro Yogyakarta menawarkan tiga pilihan kepada konsumen untuk layanan rapat dan banquet ini, antara lain coffee break, makan siang, atau makan malam. Tamu dapat memilih salah satu dari tiga pilihan tersebut atau ketiga-tiganya. Seperti layanan sarapan, layanan rapat dan jamuan disajikan dengan konsep buffet atau prasmanan di mana tamu dapat mengambil sendiri makanan dan minuman yang telah disediakan.

Harga untuk coffee break di Hotel Amaris Diponegoro Yogyakarta mulai dari Rp 40.000,- hingga Rp 50.000,- per orang. Menu untuk coffee break telah mengikuti standar sesuai tabel berikut:

\section{Tabel 2. Daftar Menu Coffee Break}

\begin{tabular}{|c|c|c|c|}
\hline \multicolumn{4}{|c|}{ Daftar Menu Coffee Break seharga Rp 40.000,- } \\
nett
\end{tabular}

Sumber: Data dari Departemen F \& B Hotel Amaris

Tamu yang hendak memesan coffee break untuk suatu acara akan diminta memilih satu dari pilihan daftar menu seperti terlihat di tabel 2 dan menyebutkan jumlah yang dikehendaki. Pemilihan menu dan penetapan jumlah tersebut dimaksudkan agar staf F \& B dapat mempersiapkan kebutuhan sesuai permintaan. Selain itu, menu coffee break di atas merupakan kombinasi antara menu hotel dan menu mitra Departemen F \& B. Menu hotel adalah menu coffee break yang disiapkan oleh Departemen F \& B Hotel Amaris, seperti pisang rebus, tahu goreng, mendoan, jagung rebus, pisang goreng, kacangm tape goreng, dan bakwan. Sedangkan menu yang lain dipesan dari toko roti mitra Hotel Amaris.

Menu makan siang dan makan malam untuk rapat dan jamuan dikelompokkan menjadi à la carte dan as per chef. Menu à la carte memungkinkan tamu untuk memilih makanan dari daftar 
menu dan mengkombinasikannya dengan pilihan menu lain. Apabila tamu memiliki sejumlah dana, mereka dapat memilih daftar menu yang telah disusun oleh Departemen F \& B Hotel Amaris. Harga satu paket makan siang atau makan malam mulai dari Rp 75.000,- hingga Rp 80.000,per orang. Daftar menu à la carte dan as per chef dapat dilihat di tabel berikut.

Tabel 3. Daftar menu à la carte

\begin{tabular}{|c|c|}
\hline Menu & Harga \\
\hline Nasi goreng & $\operatorname{Rp} 35,000$ \\
\hline Mie Goreng/ rebus & $\operatorname{Rp} 35,000$ \\
\hline Bihun Goreng/ rebus & Rp 35,000 \\
\hline Ayam Goreng Bacem & $\operatorname{Rp} 45,000$ \\
\hline SopKonro & $\operatorname{Rp} 60,000$ \\
\hline Soto Ayam & $\operatorname{Rp} 30,000$ \\
\hline Gado-gado & $\operatorname{Rp} 25,000$ \\
\hline Nasi & $\operatorname{Rp} 10,000$ \\
\hline Kentang Goreng & $\operatorname{Rp} 20,000$ \\
\hline Pisang Goreng & $\operatorname{Rp} 20,000$ \\
\hline Mendoan & $\operatorname{Rp} 20,000$ \\
\hline Tahu Isi & $\operatorname{Rp} 20,000$ \\
\hline Lumpia & $\operatorname{Rp} 20,000$ \\
\hline
\end{tabular}

Sumber: Data Departemen F \& B Hotel Amaris

Tabel 3 di atas merupakan daftar menu à la carte yang dapat dipilih untuk acara rapat, pertemuan atau jamuan. Tamu dapat lebih leluasa mengkombinasikan pilihan makanan yang mereka kehendaki. Tabel 4 (di lampiran) berisi daftar menu as per chef dengan dua pilihan harga. Tamu yang tidak ingin repot mengkombinasikan makanan dapat memilih menu ini.

Staf Departemen F \& B Hotel Amaris yang mengurus layanan rapat dan banquet adalah staf yang bertugas pada shift pagi atau shift tengah. Koki pada shift pagi bertugas memasak dan menyajikan makanan sesuai permintaan. Sementara itu, koki pada shift tengah harus melakukan hal yang sama apabila acara yang diselenggarakan menghendaki coffee break dan makan malam.

\section{d. Layanan Meja}

Layanan meja atau table service merupakan layanan makan siang dan makan malam untuk tamu baik yang menginap maupun yang tidak menginap di hotel. Karena Hotel Amaris Diponegoro adalah budget hotel, daftar menu untuk table service terbatas. Misalnya, ada nasi goreng, mie goreng, sop, kopi, teh, coklat panas, dan sebagainya. Berikut gambar daftar makanan dan minuman untuk table service.

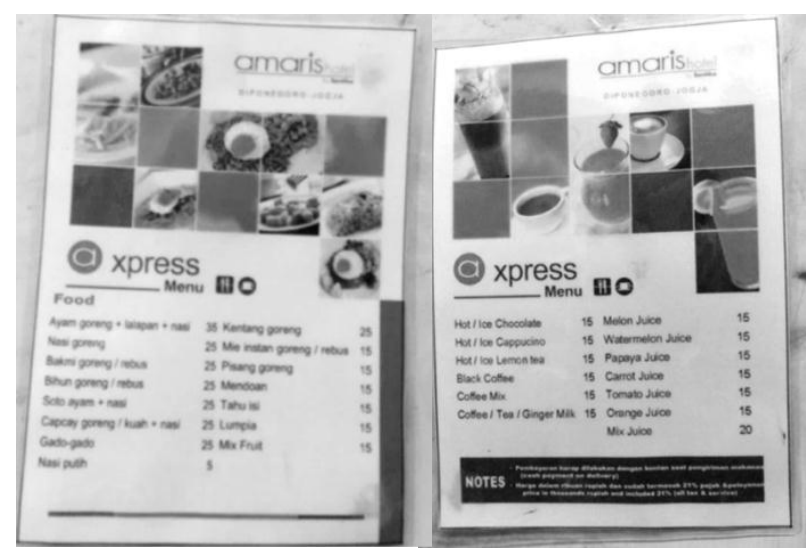

Gambar 4. Daftar Menu Layanan Meja

Sumber: Luckyrainita, 19 Mei 2015

Alur layanan meja dimulai dengan tamu yang memesan makanan dan minuman ke staf resepsionis. Setelah itu, staf resepsionis akan menelpon $\mathrm{F} \& \mathrm{~B}$ dan menyampaikan pesanan tamu. Sementara itu, tamu diminta menunggu di @xpress. Koki yang telah menerima daftar pesanan akan menyiapkan makanan dan minuman dan menyajikannya kepada tamu di @Xpress. Setelah pesanan datang, staf resepsionis akan mengantarkan tagihan kepada tamu sebelum makan dan tamu diminta membayar terlebih dahulu.

Semua koki di Departemen F \& B Hotel Amaris bertanggung jawab dalam melayani permintaan tamu pada layanan 
meja. Permintaan layanan meja dapat datang sewaktu-waktu baik pagi, siang ataupun malam. Bahkan, jika diperlukan, koki meminta bantuan staf resepsionis untuk membantu menyajikan pesanan tamu ketika koki masih memiliki banyak kesibukan di dapur. Layanan tersebut menunjukkan bahwa di Hotel Amaris memiliki kerjasama antar bagian sangat penting.

\section{e. Layanan Kamar}

Layanan makanan dan minuman di Hotel Amaris yang terakhir adalah layanan kamar. Layanan ini dipersiapkan untuk tamu yang menginap di hotel untuk alasan tertentu. Sebagai contoh, seorang tamu yang menginap di hotel yang sedang merasa kurang enak badan dan tidak dapat makan pagi di @xpress dapat meminta staf dapur untuk mengantaran makanan ke kamar. Menu untuk layanan kamar ini sama dengan menu sarapan dan layanan meja.

Menurut disertasi yang berjudul" Room Service Principles and Practices: An Exploratory Study" terdapat enam tahapan dalam layanan kamar, antara lain pra persiapan, penerimaan pesanan, penyampaian pesanan ke $\mathrm{F} \& \mathrm{~B}$, penyiapan pesanan, pengantaran pesanan, kegiatan pasca pemesanan (Suboleski, 2012). Enam tahap ini telah dilaksanakan oleh staf $F$ \& B Hotel Amaris Yogyakarta. Tahap pertama, pra persiapan, terdiri dari persiapan di dapur untuk tiap shift-nya yang meliputi persiapan peralatan masak. Peralatan makan, dan persiapan bahan makanan dan minuman. Tahap selanjutnya adalah penerimaan pesanan atau order taking. Tamu di Hotel Amaris dapat menelepon staf resepsionis dari kamar mereka dengan menekan 0 dan menyampaikan pesanan makanan dan minuman mereka. Tahap selanjutnya adalah penyampaian pesanan atau order routing ke bagian F \& B. Di Hotel Amaris, staf resepsionis akan menelepon $\mathrm{F}$ \& B dan menyampaikan pesanan makanan dan minuman tamu. Tahap keempat adalah penyiapan makanan dan minumanatau order preparation. Tahap ini dilakukan oleh koki di dapur. Tahap kelima adalah pengantaran pesanan atau order delivery. Setelah pesanan siap, koki atau staf resepsionis Hotel Amaris akan mengantarkan pesanan ke kamar tamu beserta tagihan yang harus dibayar terlebih dahulu oleh tamu sebelum menikmati pesanan mereka. Tahap ke enam adalah kegiatan pasca pemesanan atau post order activities. Suboleski dalam tahap ini menekankan bahwa hotel sebisa mungkin memiliki suatu sistem elektronik atau sistem komunikasi antara F \& B dengan bagian accounting atau front officel resepsionis dalam pencatatan tagihan layanan kamar ini. Hotel Amaris belum memiliki sistem elektronik sehingga staf dapur atau staf resepsionis mengantarkan tagihan dan menerima uang pembayaran atas layanan kamar. Pada tahap keenam ini Suboleski menyarankan pihak hotel untuk menjaring masukan atas layanan kamar tidak hanya dengan form kuesioner tetapi juga dengan menelpon tamu seusai menerima layanan kamar untuk memastikan semua pesanan telah diterima dan ada tidaknya pesanan tambahan. Tahap tersebut perlu dilakukan oleh F \& B Hotel Amaris Diponegoro Yogyakarta untuk meningkatkan layanan kamar.

\section{Tantangan di Departemen F \& B Hotel Amaris Diponegoro Yogyakarta}

Staf F \& B Hotel Amaris Diponegoro Yogyakarta dalam menjalankan tugasnya menghadapi beberapa tantangan, antara lain manajemen waktu, komunikasi antar 
staf F \& B, dan tantangan dalam melayani tamu. Untuk lebih jelasnya, masing-masing tantangan diuraikan sebagai berikut.

\section{a. Manajemen Waktu}

Tantangan terkait manajemen waktu hanya terjadi apabila ada acara yang diselenggarakan bersamaan di hari yang sama. Sebagai contoh, pada satu hari yang sama staf F \& B harus menyiapkan sarapan, coffee break, dan makan siang dengan jadwal berurutan. Pemberitahuan tentang coffee break dan makan siang biasanya sudah disampaikan seminggu sebelumnya. Oleh karena itu, staf dapur akan menyiapkan semua keperluan sehari sebelumnya. Selain itu, koki juga harus menyesuaikan dengan menu yang dipesan agar dapat menyiapkan bahan-bahan yang sesuai. Karena koki di Departemen F \& B Hotel Amaris bekerja sesuai shift, maka mereka harus berbagi tugas dalam menyiapkan semua layanan yang diperlukan.

\section{b. Komunikasi antar Staf F \& B}

Komunikasi merupakan aspek penting pada Departemen F \& B karena mutlak diperlukan untuk berkoordinasi antar staf dapur dalam rangka menjamin kualitas dalam memberikan layanan makanan dan minuman kepada tamu. Frost (2015) menyatakan bahwa orang yang bertanggung jawab di dapur perlu menetapkan standar komunikasi dan prosedur sehingga semua staf dapur tahu apa yang perlu dikerjakan. Pernyataan ini menjelaskan fungsi penting komunikasi di dapur. Kesalahpahaman dalam berkomunikasi terjadi di Departemen F \& B Hotel Amaris Diponegoro Yogyakarta. Sebagai contohnya adalah kesalahpahaman terkait macaroni untuk menu sarapan. Koki Ani telah merebus macaroni sebagai pelengkap sup untuk menu sarapan hari berikutnya, tetapi dia belum menyampaikannya ke Koki yang lain. Akibatnya, Koki Rio baru menemukan makaroni di lemari pendingin dua hari kemudian. Makaroni tersebut tentu saja sudah tidak layak diolah. Departemen F \& B Hotel Amaris Diponegoro Yogyakarta mengadakan briefing untuk mengatasi masalah seperti itu di setiap awal shift kerja, setiap hari sehingga semua staf berkomunikasi dengan lebih baik.

\section{c. Tamu}

Tantangan yang terakhir yang dihadapi oleh staf Departemen F \& B Hotel Amaris Diponegoro Yogyakarta adalah tamu. Tamu wajib mendapatkan fasilitas dan layanan terbaik dari hotel. Ada beberapa permintaan tamu yang membuat koki hotel kewalahan dalam memenuhi permintaan mereka. Tantangan dari tamu ini biasanya terjadi pada akhir pekan karena ada banyak tamu yang menginap di hotel. Hal ini menambah beban pekerjaan staf dua kali lipat dari hari biasa, khususnya untuk staf F \& B. Staf F \& B mengatasi tantangan ini dengan memperhatikan permintaan tamu dan memberikan layanan kepada tamu sesuai permintaan mereka. Selain itu, jika ada keluhan terkait makanan dan minuman, koki yang meminta maaf terlebih dahulu dan mengganti makanan dan minuman dengan yang baru.

\section{Kesimpulan}

Departemen F \& B merupakan salah satu bagian di hotel Amaris yang menyumbang pemasukan sebesar $20 \%$ dari total penerimaan hotel. Oleh karena itu, layanan F \& B di suatu hotel merupakan hal yang penting dipelajari. Terdapat dua jenis layanan F \& B di hotel Amaris Diponegoro 
Yogyakarta yaitu service unit dan selfservice unit. Service unit terdiri dari Layanan Meja dan Layanan Kamar, sedangkan Selfservice unit terdiri dari Layanan Sarapan, Layanan Welcome Drink, serta Layanan Rapat dan Banquet. Staf menghadapi beberapa tantangan dalam menjalankan pekerjaan di Departemen F \& B, antara lain manajemen waktu, komunikasi antar staf, dan tamu. Tantangan terkait manajemen waktu muncul ketika ada beberapa acara yang diselenggarakan pada hari yang sama di hotel. Staf F \& B mengatasi hal ini dengan berbagi tugas. Komunikasi antar staf F \& B yang kurang bagus merupakan tantangan selanjutnya. Masalah komunikasi tersebut dapat diatasi dengan briefing di setiap awal pergantian shift. Tantangan yang terakhir adalah tamu yang harus dilayani dengan memberikan fasilitas dan layanan yang terbaik. Staf F \& B mengatasi hal ini dengan lebih memperhatikan permintaan tamu dan memberikan layanan sesuai dengan permintaan tamu.

\section{Daftar Pustaka}

"Difference Between Hotel and Motel." Diunduh dariSetupmyhotel.com. 17 Sept. 2015.

"The Food and Beverage Department Database." Printed. 19 May 2015.

"Amaris Hotel" [2015]. Diunduh dariAmarishotel.com./amaris-jogja. 27 July 2015.

Badan Pusat Statistik Provinsi D.I. Yogyakarta. "Akomodasi Kamar dan Tempat Tidur Hotel Menurut Kabupaten/ Kota D.I. Yogyakarta, 2006-2015". Diunduh dari https://jogjakota.bps.go.id.

27 Feb 2017.
Danilo, Alfaro. “À la Carte.”[2015]. Diunduh dariCulinaryarts.about.com. 19 Sept. 2015.

Davis, Bernard, and Stone, Sally. [1985]. Food \& Beverage Management. Oxford: Heinemann Professional Publishing.

Elements of business skills for upper secondary.[2015]. Singapore: Pearson Education South Asia, 2008. retrieved6 July 2015.

Frost, Shelley. "Examples of How to Communicate in a Kitchen." Diunduh dari Smallbusiness.chron.com. $\quad 20$ Sept.2015.

Kazarian, Edward A. [1983]. Food Service Planning. $2^{\text {nd }}$ ed. Westport: Avi Publishing Company.

Pendit, Nyoman S. dan Soekresno. (1998). Petunjuk praktek pramusaji Food and Beverage Service. Jakarta: PT. Gramedia Pustaka Utama.

Saputra, Yohanes Rio F. Personal interview. 19 May 2015.

Suboleski, Stanley D. (2012). "Room Service Principles and Practices: An Exploratory Study." UNLV Thesis, Dissertations, Professional Papers and capstones. 1780. Diunduh dari http://digitalscholarship.unl v.edu/thesesdissertations/1780 Sulastiyono, Agus. (2004). Manajemen Penyelenggaraan Hotel. Bandung: Alfabeta.

Trainor, Robert.(2017). "Food \& Beverage Banquets a la carte".n.d. Diunduh darihotelexecutive.com/business_r eview/215/banquets-a-la-carte 


\section{Lampiran}

\section{Tabel 4. Daftar menu As Per Chef}

\begin{tabular}{|c|c|c|}
\hline \multicolumn{3}{|c|}{ Daftar menu dengan harga Rp 75,000 nett } \\
\hline A & B & C \\
\hline Nasi & Nasi & Nasi \\
\hline Nasi Goreng & Nasi Goreng & Nasi Goreng Ikan Asin \\
\hline Tradisional & Telur & Tumis Kacang Panjang \\
\hline Tumis Kacang & Ca Sayur & Ayam goreng krispi \\
\hline Panjang & Gulai Ayam & Gulai daging \\
\hline Ayam Bakar & Ikan Goreng & Bakwan \\
\hline Cumi Goreng & Perkedel & Acar, Sambal, Kerupuk \\
\hline Tahu Bacem & Acar, & Buah \\
\hline Acar, Sambal, & Sambal, & Es Campur \\
\hline Kerupuk & Kerupuk & Air mineral \\
\hline Buah & Buah & \\
\hline Puding & Puding & \\
\hline Air mineral & Air mineral & \\
\hline \multicolumn{3}{|c|}{ Daftar menu dengan harga Rp 80.000 nett } \\
\hline A & B & $\mathbf{C}$ \\
\hline Sop Ayam Jamur & Sop Buntut & Sop Ikan campur \\
\hline Nasi & Nasi & Nasi \\
\hline Nasi Goreng & Nasi Goreng & Nasi Goreng Kuning \\
\hline Kampung & Mawut & Tumis Bayam \\
\hline Sayur Pencok & Tumis & Ayam Goreng \\
\hline Ayam Bakar & Kangkung & Daging Rica-rica \\
\hline Gurameh & Ayam & Perkedel \\
\hline Tempe goreng & Goreng & Acar, Sambal, Kerupuk \\
\hline Acar, Sambal, & Bacem & Buah \\
\hline Kerupuk & Chicken & Rebusan \\
\hline Buah & Ikan Pesmol & Puding \\
\hline Es Degan & Bakwan & Air mineral \\
\hline Puding & Acar, & \\
\hline \multirow[t]{6}{*}{ Air Mineral } & Sambal, & \\
\hline & Kerupuk & \\
\hline & Buah & \\
\hline & Es Cendol & \\
\hline & Puding & \\
\hline & Air mineral & \\
\hline
\end{tabular}

Sumber: Data Departemen F \& B Hotel Amaris 